\title{
The 2017 John Gaus Award Lecture: What If We Took Professionalism Seriously?
}

\author{
James L. Perry, Indiana University, Bloomington
}

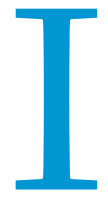

$\mathrm{t}$ is a distinct honor to be recognized for career achievements with the John Gaus Award. My thanks to my nominators, the Gaus Award selection committee, my wife and family, and the many mentors, students, and collaborators who have supported me throughout my career. In particular, I would like to acknowledge the School of Public and Environmental Affairs at Indiana University, Bloomington for being a congenial home for my professional life since 1985 .

One of the first articles I read as a graduate student was John Gaus's (1947) "Ecology of Government," so I have long been aware of John Gaus's standing in the fields of political science and public administration. I was not aware, however, of just how important John Gaus's contributions were to the early years of public administration in the United States until I began preparing this essay. It is indeed my pleasure to be associated with his legacy.

My priorities and attention during the past six years were shaped significantly by my role as editor in chief of Public Administration Review (PAR), which for the past 77 years has been the preeminent outlet for both scholars and practitioners of public administration. My choice of topic for this essay-professionalism in public administration-is a product of my experiences as PAR's editor. My topic also has roots in my graduate student days, when I first became concerned about what public administration represented and what that meant, not only for the field's identity, but for my own identity, too.

As PAR editor, I have had a less-than-encouraging venture with professions. In 2012, in preparation for the American Society for Public Administration's (ASPA) 75th anniversary in 2014, I issued a call for submissions (Public Administration Review 2012) about cutting-edge perspectives on public service professionalism. My questions prompted consideration about the status of public administration as a profession and the means by which public service professionalism is assessed: Is there a public service professionalism? What metrics can be developed to assess professionalism in public service? What is the role of oaths, codes of conduct, and accreditation? How can the professions and professionals be developed for public service? The call yielded about 40 proposals. I authorized about 25 of the proposals to be developed into papers for peer review. PAR ultimately published just two of the papers submitted for review. Despite a relatively strong response to the call, we were not able to surface cutting-edge perspectives on public service professionalism.

James L. Perry is distinguished professor emeritus and chancellor's professor emeritus at Indiana University's School of Public and Environmental Affairs. He may be reached at perry@indiana.edu.
My failed search for content was frustrating. Subsequent experiences as $P A R$ 's editor did not alter my impressions. This inability to unearth meaningful scholarship on these topics has left me with the conviction that the field still lacks the tools and grounding to speak authoritatively about public professionalism. I am not alone in my frustration (Streib n.d.), but I have no easy or quantifiable way to measure the felt frustration among others in the field. This essay is intended to prompt a solution by making the case for more robust research and attention to professionalism in public administration. ${ }^{1}$ Doing so would, I believe, provide not only a means to establish a clear identity for the field but also a context for important aspects of public administration theory and research, as well as a pathway for integrating disparate research streams.

My thesis: Public administration would be well served to pursue professionalism as a core theme because it is a central construct for understanding and acting in public administrative contexts. Although public administration has occasionally embraced professionalism, such efforts have failed to stimulate a critical mass of scholarly and practitioner activity. This essay presents the case for professionalism in three stages. First, I highlight literature that emphasizes professionalism as a means of establishing an identity for public administration, and I assess progress to date. Next, I offer some ideas for setting a course to make professionalism a robust feature of public administration. I conclude with a discussion of benefits that could accrue from pursuing these proposals.

The title of this essay is crafted to remind readers of previous articles that had a similar purpose and were influential in popularizing lines of research that, prior to their publication, had received only modest attention. One of them is by Laurence J. O'Toole, a Gaus Award winner and my classmate at the Maxwell School at Syracuse University, titled "Treating Networks Seriously: Practical and Research-Based Agendas in Public Administration" (O'Toole 1997), which was recognized in 2015 as among PAR's 75 most influential articles. ${ }^{2}$ I have no pretense that this treatise will be as influential as Larry's, but there is no harm in trying!

\section{PUBLIC ADMINISTRATION'S EMBRACE OF PROFESSIONALISM}

We begin with a definition of profession from William Sullivan: 
This definition, or a close approximation of it, has been the starting point for discussion and debate about professions in public administration since at least the 196os. Throughout this essay, I'll unpack this definition and examine its applicability to public administration.

Professions and professionalism have long been important in public administration (see Gargan 2006 for an extensive review of the literature). The concept of merit (Ingraham 1995), upon which the field was founded, is a precursor to the ideas we associate with professionalism today. The Progressives embraced the ideas embedded in professions; the movement was the source of many "polity professions" (civic service professions), among them city managers, social workers, and political scientists (Stever 1987).

Although I have not sought to identify the first substantive reference to "profession" in the public administration and political science literatures, we do know that John Gaus was a champion for the professions long before the term became popular in the public administration literature. In "The Responsibility of Public Administration" he writes: professions in public service and their influence in shaping policy and its implementation. Mosher wrote:

Our dependence upon professionals is now so great that the orientations, value systems, and ethics which they bring to their work and which they enforce on one another are a matter of prime concern to those who would strengthen the democratic system (Mosher 1968, 10).

Beyond the issue of the incidence of professionals in public service, Mosher was interested in who controlled them and to whom they were accountable.

For better or worse-or better and worse-much of our government is now in the hands of professionals (including scientists). The choice of these professionals, the determination of their skills, and the content of their work are now principally determined, not by general governmental agencies, but by their own professional elites, professional organizations, and the institutions and faculties of higher education (Mosher 1968, 132).

\section{Having studied under Waldo and having cut my scholarly teeth on Mosher, I attempted to} bring a similar focus to professionalism in my own work. In three editions of the Handbook of Public Administration (Perry 1989; Perry 1996a; Perry and Christensen 2015), I was very intentional to emphasize the professional dimension of public administration.

\begin{abstract}
Throughout the country the professional organizations of public servants ... are similarly working in close association with university departments of political science and with governmental research organizations in the effort to improve the quality of administration and to introduce the note of research, inquiry, and self-examination into the day-to-day life of the public servant (Gaus 1936, 41-42).
\end{abstract}

His observations about responsibility and the administrative profession were not limited to the United States alone. He commented about developments in Great Britain, Germany, and Scandinavia. At the time of his observations, Gaus saw "the attitude of the civil servant as an individual toward his work and his profession" $(1936,43)$ as the most important driver of responsibility.

\section{8 as a Pivotal Juncture}

The year 1968 may have been a watershed in the field's embrace of professionalism. Dwight Waldo (1968), analyzing the scope of the theory of public administration, proposed that public administration adopt a professional perspective as a way to address its identity crisis. Waldo $(1968,10)$ wrote: "What I propose is that we try to act as a profession without actually being one, and perhaps even without the hope or intention of becoming one in any strict sense." Waldo endorsed the spirit of professionalism, but was clearly reluctant to embrace all its implications.

In the same year that Waldo thus reflected about the direction of the field, Frederick Mosher published the first edition of his influential Democracy and the Public Service (1968). Arguably, the most influential aspect of Mosher's book was his attention to the professions. It is hard to imagine today, but Mosher's focus on the importance of professionals was relatively novel at the time. Scholars had previously given little formal recognition to
Having studied under Waldo and having cut my scholarly teeth on Mosher, I attempted to bring a similar focus to professionalism in my own work. In three editions of the Handbook of Public Administration (Perry 1989; Perry 1996a; Perry and Christensen 2015), I was very intentional to emphasize the professional dimension of public administration. The preface to each edition acknowledged the professional nature of public administration, as did the last part of each edition, which was titled "The Professional Practice of Public Administration." I wrote in the preface to the first edition (Perry 1989): "Written by public administration experts from all areas of the field-law, politics, public policy, finance, personnel, operations, and others-it is designed to meet the needs of the range of professionals who work in government or interact with public agencies" (xiv).

\section{How Have We Done?}

Nearly three decades after Waldo (1968) first proposed embracing profession as a means to clarify the field's identity, Philip Jos and Mark Tompkins (1995) assessed the results of the drive toward professionalism. Their conclusion was direct and unequivocal: the professional focus has not helped and should be relinquished. Their critique rests on the premise "that appeals to professionalism fail to take account of the diversity of tasks performed in the public sector and tend to mis-characterize the sort of complexity that public managers and other public employees encounter" (Jos and Tompkins 1995, 208). They concluded that the professional ideal, even if revised to avoid claims to autonomous practice, should be abandoned.

While I agree with Jos and Tompkins (1995) that the field of public administration has not reaped the benefits that Waldo and others expected from a focus on professionalism, I dispute their conclusion that such a focus is futile. The reasons the field has not 
reaped expected benefits is multi-faceted, and includes a failure to frame research about professionalism to capture the diversity and complexity of public service, a dearth of empirical research to ground our understanding of professions and professionalism in public service, and expectations that exceeded what a professionalism focus could achieve. Given these limitations in the efforts that preceded their analysis, I disagree with Jos and Tompkins' (1995) conclusion that professionalism should be abandoned. I offer instead some ideas for redirecting the way the field thinks about professionalism to make this effort more robust and sustainable.

\section{WHAT IS PROPOSED AS A WAY FORWARD?}

Taking professions seriously requires a renewed commitment from public administration in which scholars embark on a mission of building knowledge about professions in public service. The discussion below sets out details of my proposal.

One facet of professions in public administration that is largely uncontested is Mosher's point that public service is professional. March 2017 is the latest report for which US federal employment data are available. FedScope puts total federal employment at $2,087,715$. The total number of employees classified as professional is 568,867 , more than $25 \%$ of total US federal employment. Identifiable professions are well represented, including nurses $(84,522)$, medical officers $(34,876)$, general attorneys $(38,489)$, and general engineers $(26,691)$.

Despite this occupational representation in public service, the discussion of professions turns contentious when the reality or desirability of one or more of the attributes of professions comes into play. This forum does not permit me to discuss the controversies at any length, but I can identify some of the contours of the debate. They include: (1) threshold questions about the amount and nature of training to qualify an occupation as a profession; (2) concerns about the implications of autonomy and self-regulation for democratic governance and accountability (Green, Keller, and Wamsley 1993); and (3) whether professions obligate their members to commitments to public service that transcend the economic welfare of individual members. Although these debates have stalled movement on public administration's professional agenda, I believe progress is possible. In the next section I discuss steps to facilitate progress.

\section{How Should We Conceive Professionalism in Public Contexts?}

I propose alternative ways to think about professionalism in public service to lead us from the cul-de-sac in which we have been lost for the quarter century since Green et al. (1993) and Jos and Tompkins (1995) offered their assessments. My proposal has four parts:

1. Concept names. Adopt an alternative concept name to capture the phenomenon of interest to convey the limitations of the sociological meanings of profession when studying the phenomenon in the public administration context. The construct name "public service professionalism" seems better suited to the history and intent of the construct in public administration than other iterations of "profession."

2. Construct dimensionality. Accept a two-pronged conceptualization of public service professionalism as (1) instrumental, focused largely on effectiveness of administrative action, and (2) normative, attentive to the substance and fidelity of obligations to the governance regime.
3. Multi-level units of analysis. Public service professionalism, and the normative obligations of public servants (Waldo 1988), is a complex phenomenon. Research about public service professionalism should incorporate several levels of analysis, ranging from institutions to operations.

4. Plural in contrast to universal. We are unlikely to encounter a universal public service professionalism. Instead, multiple conceptions of public service professionalism are likely to coexist due to the complex institutional and structural arrangements in which public administrators are embedded.

\section{Concept Name}

I learned early in my career that concept names can make a difference in launching a research agenda. As an assistant professor, I first encountered the issue in the context of research on organizational commitment (Angle and Perry 1981; Angle and Perry 1983). I benefitted from observing my first dean and distinguished scholar, Lyman Porter, his PhD students, and their research team build the concept of organizational commitment from inchoate phenomena into a highly regarded and influential line of research (Mowday, Porter, and Steers 1982). It was clear that in selecting the concept name, they were able simultaneously to capture its attributes and differentiate it from everyday language that impeded scientific progress.

This lesson about the importance of concept names can be applied to public administration scholars' study of professions. Dwight Waldo's (1968) dislike for using the professional label lingers to this day. References to professions often include concerns expressed about "narrow and selfish professionalism" (Gaus 1936, 43), undemocratic autonomy (Rosenbloom 1982; Green, Keller, and Wamsley 1993), technical professionalism (Brint 1994; Perry 2007), distorting appreciation of "broad public policy issues" (Schott 1976, 257), and diminishing popular participation and popular control (Bowman 1982-83). Public administration has embraced professions and professionalism, but it is obvious that many commentators, particularly scholars, are not happy about that choice!

A solution to the tension associated with terminology is to change the rhetoric (Green, Keller, and Wamsley 1993) and move toward more broadly accepted labels that carry less baggage. I envision using three terms, in complementary ways, to reduce terminology-related tensions: profession; professionalism; and public service professionalism.

\section{Profession}

Profession is the term that carries the specialized meaning long associated with sociological study of professions. It represents a particular but widespread form of social stratification, that is, social structure that is an undeniable influence in public organizations and policy. Although public administration scholars have been critical of aspects of what professions represent, such as the tendency for professions to seek autonomy in applying specialized knowledge, the normative implications of the concept for public administration can be mitigated without abandoning its study in public administration.

\section{Professionalism}

Professionalism is the conduct and qualities of a professional. Professionalism is behavioral and includes conduct involving not only the use of specialized knowledge, but also competence, honesty and integrity, accountability, and self-regulation. 


\section{Public service professionalism}

This term encompasses behaving in ways compatible with both the standards of the specialized expertise of a profession and norms dictated by the action contexts in which an individual is embedded. Professionalism is the general conduct and qualities of a professional, whereas public service professionalism is specific to particular public service roles such as city manager or environmental engineer.

\section{Concept Dimensionality}

The terminology I propose above implies at least a duality to the study and practice of professionalism in public administration. The duality to which I refer is the instrumental/normative distinction so common in the public administration literature. Green, Keller, and Wamsley $(1993,516)$, for example, contend that our attention to professionalism is impoverished because we have cast
The appropriateness of the IAD framework derives from its three distinct, nested "worlds of action" (Bekke, Perry, and Toonen 1996; Kiser and Ostrom 1982). These three worlds of actionnamely constitutional, collective choice, and operational-mirror analytic distinctions that have long been deemed consequential in the public professions literature. Green et al. (1993), for example, distinguish among professional, constitutive, and normative competence, a three-way distinction that is compatible with the operational (i.e., professional), collective choice (i.e., constitutive), and constitutional (i.e., normative) worlds of action. The correspondence between Green et al. (1993) and the IAD framework is strong and therefore could be fruitful for advancing calls for integrating public administration and political science research (Amsler 2016).

In contrast, the new-logic model proposed by Lynn, Heinrich, and Hill (2001) rests on a research strategy for studying governance

\section{A solution to the tension associated with terminology is to change the rhetoric (Green, Keller, and Wamsley 1993) and move toward more broadly accepted labels that carry less baggage. I envision using three terms, in complementary ways, to reduce terminology-related tensions: profession; professionalism; and public service professionalism.}

our intellectual attention to instrumental and descriptive facets of professionalism (how things are done) and ignored its normative dimension (determining what must be done).

To more accurately and meaningfully interpret public service professionalism, the instrumental/normative duality cannot represent an either-or choice. Instead, our attention to professionalism must simultaneously include instrumental and normative dimensions. In many ways, the professionalism focus helps to answer the question about "the place of normative values" raised by Robert Dahl (1947). Dahl's exhortation was:

\section{The student of public administration cannot avoid a concern with ends. What he ought to avoid is the failure to make explicit the ends or values that form the groundwork of his doctrine. If purposes and normative considerations were consistently made plain, a net gain to the science of public administration would result (3).}

This focus on normative values brought a new dimension to public administration scholarship. Wright (2015) argued, in his review of the aftermath of Dahl's (1947) assessment of public administration as a science, that scholars have made demonstrable progress acknowledging and studying values. Among the recent research publications that led Wright to his conclusion are Brown, Potoski, and Van Slyke (2006), Rosenbloom (2007), Nabatchi (2012), and Moynihan et al. (2011). ${ }^{3}$

\section{Multi-level Units of Analysis}

Within public administration scholarship, we already have several multi-level frameworks that could provide the analytic foundation for what I propose. For example, two frameworks are particularly consistent with the spirit of the proposal: the institutional analysis and development framework (IAD) and the "new-logic model" for governance research (Lynn, Heinrich, and Hill 2001). rather than an explicit nested model. They define governance "as regimes of laws, rules, judicial decisions, and administrative practices that constrain, prescribe, and enable the provision of publicly supported goods and services" (Lynn, Heinrich, and Hill 2001, 7). As I have previously articulated, the intent of their framework is to promote:

studies that develop theory-based, multi-component models that are empirically verifiable, that define and operationalize concepts, and that present appropriately framed findings ... [the] model flows hierarchically...from the global/national/cultural environment, to the institutional level, to the managerial level, to the technical level, to political assessment (Perry 2002, 744).

Although Lynn, Heinrich, and Hill do not mention the IAD framework, they explicitly acknowledge their debt to mainstream social scientists such as Talcott Parsons and James D. Thompson, further establishing the link between public administration and social science.

\section{Plural in Contrast to Universal}

Public administration scholars who have written about professionalism are critical of the simplicity of extant approaches, but the alternatives they propose are themselves simplistic. They have tried to define a universal professional framework for a public administration "class." The "universal" position is transparent, for example, in the title of Green, Keller, and Wamsley's (1993) article, "Reconstituting A Profession" (emphasis added). Although there may be universals, such as constitution-level rules that prescribe professional behavior or professionalism, the diversity of the public sector suggests professional direction is likely to take plural forms.

Take, for example, the role of city manager, one of the more highly developed and self-conscious professions in government, established at the height of the Progressive era. City managers are 
subject to the same constitutional rules as virtually everyone else across the US public sector. However, they are also subject to some peculiar rules, such as the International City/County Management (ICMA) Code of Ethics and local ordinances and state statutes that govern choice processes within the jurisdictions in which they serve. These distinctions, together with the knowledge and skill repertoire necessary to serve as an effective chief operating officer, differentiates what constitutes both professionalism and public service professionalism for city managers from what these terms mean for other state or federal employees, even those occupying chief operating officer roles in other public organizations.

The city manager example helps to make another point about the need to model professionalism in plural rather than universal terms. ICMA is a membership organization that represents city managers in countries around the world (Berman 2017). Although city managers subscribe to some universals, like their and sense of direction and purpose. It has meaning and contains useful cues and imperatives both in the academic world in which public administration is studied and in the governmental world in which public administration is practiced (10).

Three factors underlie my view that professionalism will contribute to strengthening public administration's identity. First, public administration's identity is historically embedded in the language and logics of professions and professionalism. Reading classic contributions from Gaus $(1936 ; 1947 ; 1950)$ and Wilson (1887) affirms that the development of public administration professionally was a valued goal within the reform movement.

Second, governments, quasi-governments, and public servants need usable knowledge to advance their missions (Perry 2012a; 2013; Radin 2013). The creation and acquisition of usable knowledge relies on the alignment of our understanding of public administration with its broad social purpose. Characterizing public

\section{Dwight Waldo's (1968) original reason for proposing that public administration adopt a "professional perspective" was related to what he perceived as a crisis of identity that began in the aftermath of World War II and continued into the 1960 .}

code of ethics, they must also adhere to a variety of rules inherent in the country situations in which they are embedded. Thus, even city managers reflect a plural professionalism. Models that accommodate plural conceptions of professionalism are also better suited to building global, rather than particularistic, public administration knowledge (Perry 2016).

\section{WHAT DIFFERENCE MIGHT THE PROPOSAL MAKE FOR PUBLIC ADMINISTRATION?}

I can envision a variety of advantages if public administration took professionalism seriously. My vantage point and preferences, no doubt, may lead me to overstate benefits, but using professionalism to frame the field can pay off for research and practice. A robust standing for professionalism as a frame could help to realize the aspirations of people like John Gaus and pull together disparate threads long unconnected within the field. Here I briefly discuss three benefits the field could reap by being more attentive to the professionalism agenda: reaffirming public administration's identity, contextualizing important aspects of public administration theory and research, and integrating disparate research streams.

\section{Reaffirming Public Administration's Identity}

Dwight Waldo's (1968) original reason for proposing that public administration adopt a "professional perspective" was related to what he perceived as a crisis of identity that began in the aftermath of World War II and continued into the 1960 . Becoming professional for Waldo was a better direction for the field than staying a sub-discipline of political science or becoming a discipline unto itself. Waldo (1968) wrote in justification of his proposal:

The professional perspective or stance is the only one broad and flexible enough to enable us to contain our diverse interests and objectives, yet firm and understandable enough to provide some unity service as a profession, as represented by an analogy to medicine, is the frame that Waldo $(1968,10)$ and I (Perry 2012b) see as most promising for positioning the field to produce usable knowledge. The medical analogy reminds us that public administration is a practical enterprise that seeks to better the public sphere by drawing upon the physical, social, and behavioral sciences. At the same time, public administration professionals must understand and navigate the extra-cognitive aspects of public administrationjudgment, skill, and values-that are central to our modern understanding of profession (Sullivan 2005).

Third, the professional identity I am proposing is instrumental for the effective engagement of scholars and practitioners seeking to support public service. A good deal has been written about discontinuities between the academy and the world of practice, both in public administration specifically (Milward et al. 2016; Perry 2017; Volcker 2014) and the social sciences generally (Davis 2015; Lindblom and Cohen 1979; Watts 2017). The "blame" for the academy-practice divide has been assigned to many factors, among them the incentives within academe and increasing specialization that distances modern research from most practitioners. I have no doubt that whatever the determinants for the two, nonintersecting worlds (Buick et al. 2016; Newman, Cherney, and Head 2016), more interaction between the communities is necessary to develop action in concert across the communities.

The professional perspective gives us our best chance for bringing the communities together because it "has meaning and contains useful cues and imperatives both in the academic world in which public administration is studied and in the governmental world in which public administration is practiced" (Waldo $1968,10)$. A professional perspective could serve to remind scholars and professionals-and the organizations they inhabit-of the bonds between the two communities that John Gaus wrote about in 1936, which I quoted earlier. Gaus's message in "The Responsibility of Public Administration" (1936, 41-42) was implicitly about mutual responsibility. He wrote of public servants and their 
professional organizations working closely with university staff and research organizations to improve the quality of administration. His reference to introducing "research, inquiry, and self-examination into the day-to-day life of the public servant" (Gaus 1936, 41-42) suggests he had in mind not only instrumental aspects of public administration but normative values, too.

We may have an alternative to embracing professionalism, but I am not aware of it. Professionalism brings greater coherence to the unique nature of public administration. In its absence, the field is inchoate. Everyone with an interest in or commitment to public administration does not have to embody all facets of this professional identity, but to the extent that we can build a common understanding, I believe we each can more effectively contribute to a common end, which is the betterment of governance for the public interest (Bozeman 2007).

\section{Contextualizing the Study and Analysis of Values}

Although public administration research has become more specialized since John Gaus's era (Ni, Sugimoto, and Robbin 2017), scholars have been slow to move from research models and assumptions that presume public organizations are populated with public administration generalists to realistic assumptions about public administration's context and complexity.4 A robust research program about professionalism in public administration could help to contextualize existing research streams that would benefit from the new knowledge. Two such research areas are public service motivation and street-level bureaucracy.

\section{Public service motivation}

When I initiated my research about public service motivation in the early 1990s, I envisioned important intersections between research about public service motivation and professionalism (Perry 1997). In the first study of the antecedents of public service motivation, I wrote:

Professions historically have been a repository for public service values. The professions of medicine, law, and the clergy advanced such social norms as caring, social justice, and the common good. Many of these values took root in public administration with creation of the city management plan and the evolution of public service professions (185).

Despite the fact that public administration was home to polity professions (Stever 1987), professionalism was perceived as having another side that made it a double-edged sword (Willbern 1954). Disadvantages were tendencies for professional loyalty to displace loyalty to larger portions of the population and for professionals to pursue insulation from political control. Thus, I expected that the degree to which professionalism influenced public service motivation was likely to be constrained by tension between professional self-interest and the ideal of professional responsibility to higher ethical and moral standards.

The results of my analysis of public service motivation and professionalism in 1997 were surprising. I found no significant overall relationship between the two constructs, a negative relationship between professionalism and attraction to public policy making, and positive relationships between professionalism and both civic duty and self-sacrifice. The potential ties between professionalism and public service motivation appeared to be every bit as complex as the literature projected.
Although the professionalism-public service motivation relationship has received additional attention over the years, the amount of research has been modest and much of it has been conducted in Denmark. In a multi-methods study, Andersen (2009) investigated how professional norms, public-service motivation and economic incentives affected behavior and performance among a sample of Danish dentists, general practitioners, and orthopedic surgeons. She found that public service motivation, measured using a small sample of semi-structured interviews that she acknowledged as a limitation of the research, was uniformly high among the professions she studied, negating its ability to explain variations in behavior and performance. A recent study in Denmark (Andersen and Pedersen 2012) concluded that the professionalism-public service motivation relationship was more complex than scholars earlier supposed, affirming inferences from my 1997 study. They found that professionalism was negatively related to compassion and user orientation, positively related to attraction to policy making, and not related to commitment to the public interest. A related Danish study (Andersen and Serritzlew 2012) exploring a single dimension of public service motivation-commitment to the public interest-found that physiotherapists with higher scores served a higher proportion of disabled patients, for whom services were less lucrative and who were seen as more needy. The authors inferred that physiotherapists serving a higher proportion of disabled patients perceived themselves as making greater contributions to society.

Results from such studies of public service motivation and professionalism are intriguing, but underdeveloped. They might help us to penetrate the veil between the professions and important values such as accountability and democratic responsiveness. More research about public service motivation using professions as the nexus would also extend our understanding of the context for public service motivation.

\section{Street-level bureaucracy}

Another line of research that has received steady attention in public administration since it first appeared is street-level bureaucracy (Lipsky 1980; Maynard-Moody and Musheno 2003). In StreetLevel Bureaucracy: Dilemmas of the Individual in Public Services, Lipsky (1980) presented a case for understanding how public service workers influence policy implementation. The term "streetlevel bureaucrats" was used to describe front-line workers in public-facing bureaucracies, such as teachers, judges, police officers, health workers, and social workers. Lipsky (2010) made two claims about street-level bureaucrats:

\footnotetext{
The first was that the exercise of discretion was a critical dimension of much of the work of teachers, social workers, police officers, and other public workers who regularly interact with citizens in the course of their jobs. Further, the jobs typically could not be performed according to the highest standards of decision making in the various fields because streetlevel workers lacked the time, information, or other resources necessary to respond properly to the individual case (Lipsky 2010, xi).
}

Lipsky's observations make the potential intersections between research on street-level bureaucrats and professionalism immediately apparent. Discretion and autonomy are common to the literatures on street-level bureaucrats and professions. The occupational contexts overlap. Teachers, police officers, legal workers, and social workers are identifiable in both streams of research. 
It is surprising that more advantage has not been taken of the intersections as a means for accumulating a deeper knowledge base. A recent study of social workers (Evans 2010) lauds Lipsky's analysis for its insights into worker discretion, but is simultaneously critical of his limited attention to professionalism. Evans correctly notes that professional status influences both the extent of discretion that an occupational group exercises and the values that inform its use of discretion. Evans' contention is that these social structures and rules deserve to be included in analysis of the behavior of street-level bureaucrats. To date, however, they have not received the attention they deserve. Using research on professions to contextualize the study of street-level bureaucracy is a move to remedy this important gap in research.

\section{Integrating prominent research streams}

A third difference a vigorous program of research on professionalism could make is to help integrate disparate lines of research. Two examples of research streams that could be more effectively integrated through attention to public service professionalism are public values research and regime legitimacy research.

\section{Public values research}

Research about values in public administration has figured prominently in the field since the 1940s. Herbert Simon (1946) and Robert Dahl (1947) ignited controversy about values that echoes to this day. My proposal puts values at the center of the field in ways that address issues first raised by these scholars (Dahl 1947; Meier 2015; Simon 1946; Wright 2015). As noted above, scholars have made demonstrable progress acknowledging and studying values. More research that self-consciously considered professionalism could advance this knowledge meaningfully.

The most recent manifestation of the values debate within public administration involves several competing lines of research summarized by Bryson, Crosby, and Bloomberg (2014). They identify three streams of research identified with Moore (2014), Bozeman (2007), Jørgensen and Bozeman (2007), and Meynhardt (2009). My informal communications with colleagues reveal that the differences among these lines of research can be perceived as a cacophony. A vigorous program of research on professionalism could shed light on the relative merits of these competing lines of research. Such a program would also go a long way in grounding the debate in realities of life in public organizations.

\section{Regime legitimacy research}

An arena that represents a connection between political science and public administration in the finest tradition of John Gaus is research on regime legitimacy. Lipset (1981) defines regime legitimacy as "the capacity of the system to engender and maintain the belief that the existing political institutions are the most appropriate ones for the society" (84). Research on professionalism that includes issues such as professional values, norms and behavior offers prospects for bringing together research on regime legitimacy with research on public service motivation, public values, and public ethics.

Attraction to public-policy making (Perry 1996b) or attraction to public service (Kim et al. 2013), one of four dimensions of public service motivation, captures an individual's disposition toward the governance regime. 5 The attraction-to-public-policy-making subscale began as an effort to create an institutional dimension (Perry 1996b; Perry and Wise 1990) that tapped an individual's commitment to the governance system in which he or she operated. Among the aspects of the relationship were (1) the extent of an individual's loyalty to the governance system, (2) the individual's belief that the system was legitimate, and (3) the extent to which the individual valued the system (Perry and Vandenabeele 2015).

In their inventory of public values, Jørgensen and Bozeman (2007) identified "regime loyalty" as one of the public values in the constellation of values associated with the behavior of public servants. They also emphasized the connection of regime loyalty and other values associated with it to integrity, which comports with the original notion that this dimension captured an individual's loyalty to the institutions by which public decisions are made and executed.

The regime legitimacy concept also has ties with an important literature that pre-dates recent research on public service motivation and public values. John Rohr's scholarship (1986) is most recently associated with regime legitimacy (Feldman 2015), but the issue can be traced to Frank Goodnow (Lynn 2009) and the origins of American public administration. Thus, research on professionalism could help to integrate not only relatively recent lines of research, but also foundational research. Research on professionalism could identify the contours of to whom professionals are loyal and how their behaviors are related to regime legitimacy.

\section{FUTURE RESEARCH}

Since the 196os, when scholars followed Dwight Waldo's lead to conceptualize public administration as a profession, knowledge accumulation has lagged because, in this instance, the perfect is the enemy of the good. Scholars contested the basis for moving forward around numerous issues including questions of appropriateness, identity, normative grounding, and conceptual meaningfulness.

My sense of the field, based on more than 40 years immersed in it and monitoring it closely for the last six years from a vantage point I shared with Dwight Waldo, is that public administration is ready to move forward with a professions agenda. Recent developments in the study of public administration, among them the renewal of a behavioral public administration movement (Grimmelikhuijsen et al. 2017), increased research capacity globally (Perry 2016), and growing consensus about the centrality and nature of the field's attention to values (Bryson, Crosby, and Bloomberg 2014; Denhardt and Denhardt 2011; 2015), establish a strong foundation for future progress. Scholars and practitioners should move forward expeditiously on a professionalism agenda to fill knowledge gaps, integrate disparate research streams, and affirm an identity that has fit the reality of public administration for nearly half a century, since Waldo broached the issue in 1968.

A variety of research questions could get the ball rolling, many of them grounded in my original call for papers in 2012 (Public Administration Review). They include:

1. Is there a public service professionalism? As Mosher (1968) reminded us, government is crowded with professionals-lawyers, engineers, doctors, foresters, scientists-who are responsible for the public's business. Is there a convergence in the values espoused by most public service professions? How does the normative order of public service professions converge? What are the obligations, the responsibilities, to which all public service professionals should be attentive? Is there a lowest common denominator? Is there a high standard to which all public service professionals should aspire? 
Of course, research about this question can go beyond simply inquiring about the status of professions in government. The research could seek to conceptualize and measure public service professionalism. As my comments about the concept indicate, public service professionalism involves several types of competence, including technical or substantive competence,
4. How can the professions and professionals be developed for public service? Professionalism as a research agenda highlights the divide between those who are educated within our public affairs and administration programs and those who serve in government and quasi-governmental organizations. The number of MPAs and MPPs that graduate each year and enter government

\section{Scholars and practitioners should move forward expeditiously on a professionalism agenda to fill knowledge gaps, integrate disparate research streams, and affirm an identity that has fit the reality of public administration for nearly half a century, since Waldo broached the issue in 1968.}

ethical competence (e.g., integrity), and values competence. Just as we sought to assess the incidence of public service motivation in the 1990 s (e.g., Crewson 1997), so too should we be investigating the incidence of public service professionalism today.

2. What metrics can be developed to assess professionalism and public service professionalism? The literature on the importance of public values has grown significantly, but we have little agreement on how to define, identify, and prioritize such values (Bryson, Crosby, and Bloomberg 2014; Moynihan et al. 2011; Nabatchi 2012). Metrics to measure both professionalism and public service professionalism need to be developed to advance this agenda, including assessing the incidence of public service professionalism referred to in the first proposed research item. ${ }^{6}$ Several scholars have suggested various metrics to help operationalize the way people in public administration conceive the field. Rosenbloom (2007), for example, faults the field for failing to protect and promote values such as individual rights, constitutional integrity, transparency, and the rule of law. He therefore proposes development of impact statements and scorecards to increase attention to democratic-constitutional values. Meynhardt (2015) proposes a theory-based scorecard to measure public value creation. These and other metrics should be pursued as ways to advance the professionalism agenda. A byproduct of doing so would be to strengthen other lines of research, such as public values research, in public administration.

3. Oaths, codes of conduct, and accreditation. The oath of the Athenian City State has been associated with Syracuse University's Maxwell School, the first US public administration program, since its founding in 1924. The ICMA code of ethics is enforced as an embodiment of stewardship for good government in local governments around the globe. The American Society for Public Administration first adopted a code of ethics in 1984 (Svara 2014). What do we know about the symbolic and instrumental value of such oaths and codes? Can we employ these codes and rules in systematic ways to improve the public standing and performance of public service professionals? Oaths and codes have rarely been studied in public administration, but they deserve attention (Monypenny 1953). Accreditation, an evolving practice (Teodoro and Hughes 2012; McCabe, Ponomariov, and Estrada 2017), is another mechanism by which professional standards directly influence public services. Although accreditation is most commonly used in health care and education, it is diffusing even more widely as an accountability mechanism and deserves new scrutiny. is dwarfed by the number of new professionals graduating and entering government. The numbers of joint JD/MPA and similar joint degrees has grown over recent decades, but the proportion of total public affairs graduate degrees is still quite small. How suitable are our models of professional education for developing public service professionals? In what ways do models for professional development need to change? The need to extend the reach of development opportunities for public service may be the biggest challenge facing schools of public affairs and administration, universities, and membership organizations such as the Network of Schools of Public Policy, Affairs and Administration (NASPAA).

5. Does the idea of public service professionalism resonate internationally? The idea of and consciousness about professionalism in American public administration is, as illustrated throughout this essay, quite recent. If profession is relatively new to the American context, what is its status around the globe? Does public service professionalism have universal attributes or is it an example of American exceptionalism? Given the global reach of some professional organizations, like ASPA and ICMA, it is reasonable to expect that professionalism would resonate internationally.

\section{CONCLUSION}

My goal has been to articulate a case for renewing and strengthening attention within public administration to professions and professionalism. In the late 1960s, Mosher (1968) and Waldo (1968) stimulated significant attention for professions and professionalism within public administration. The attention they brought to a professional identity for public administration was not entirely new, but rather continued themes embraced by John Gaus and others in the 1930 .

Although a number of scholars sought to establish a professional perspective based on Waldo's exhortation, they were unable to establish consensus on a way forward. In this essay, I have proposed ideas for re-engaging professionalism and overcoming obstacles that impede such development. Among my suggestions is to adopt an alternative concept name, "public service professionalism," to denote the uniqueness of the phenomenon in public service and to separate its study in public administration from limitations scholars associated with sociological meanings of profession. A second proposal, which addresses criticisms of "technical" professionalism and simultaneously acknowledges that public administration rests on a social contract, is for a 
two-pronged conceptualization of public service professionalism as both instrumental and normative. My third proposal argues for incorporating several levels of analysis, ranging from institutions to operations, into how we study, think about, and discern public service professionalism. Finally, I argue that public service professionalism is a plural phenomenon because of the variety associated with the complex institutional and structural arrangements in which public administrators are embedded.

Renewed attention to professionalism grounded in these proposals could pay significant dividends for the field. Public administration's identity would be reaffirmed in ways that strengthen ties between scholars and practitioners. Research on professions and professionalism could also contextualize other important lines of research, including street-level bureaucracy and public service motivation. This renewed and strengthened scholarship would also serve to integrate disparate lines of research on topics such as public values and regime legitimacy. Ultimately, the field stands to gain substantial self-awareness, coherence, and interdisciplinary integration from attention to public service professionalism, and the time is right to take professionalism seriously.

\section{ACKNOWLEDGMENTS}

My thanks to Hal Rainey and Steven Maynard-Moody for comments on an earlier draft of this essay. I am also grateful to Elisabeth Andrews for her editorial assistance and guidance.

\section{NOTES}

1. My apologies to those before me who have taken professionalism seriously Any implied criticism is not of their efforts, which in many cases I have found useful and enlightening.

2. A second example is Harold Leavitt's "Suppose We Took Groups Seriously" (Leavitt 1989), which sought to popularize the study of small groups in organizations.

3. Much of the research Wright (2015) cites post-dates Jos and Tompkins (1995) and Green et al.'s (1993) conclusions about the state of professionalism in public administration, suggesting that were these authors to re-visit the same issues they might arrive at more optimistic conclusions about professionalism.

4. John Gaus was among the first to articulate a need for more contextualization of research within the field and to actively promote it. His belief in embedding research in context is apparent from his "Ecology of Government" (Gaus 1947). In his review of the first ten years of research published in Public Administration Review, Gaus (1950) was direct about one aspect of context that received little attention from scholars until the 1970s: "The other area is that vast, multifactor, and fundamental one of substantive functional fields-of health, public works, natural resources, defense, education, housing, economic regulation. Here there is an issue that is always with us; is there a 'field of administration' that can be abstracted from the services and functions to be performed?" (p. 165).

5. Perry (1996b) includes four public service motivation subscales: (1) attraction to public policy making; (2) commitment to the public interest/civic duty; (3) compassion; and (4) self-sacrifice. Kim et al. (2013) also consists of four subscales, two that carry the same names as the 1996 subscales: (1) attraction to public service; (2) commitment to public values; (3) compassion; and (4) self-sacrifice.

6. Although I cannot pursue conceptualization and measurement in this forum, I envision some nesting among the concepts of profession, professionalism, and public service professionalism. The narrowest of the concepts, profession, includes competence associated with specific knowledge and professional values. Professionalism's conceptualization is more context dependent. Conceptualization of public service professionalism is broader than professionalism and must include public content, particularly values and institutional imperatives expected of incumbents.

\section{REFERENCES}

Amsler, Lisa Bingham. 2016. "Collaborative Governance: Integrating Management, Politics, and Law." Public Administration Review 76 (5): 700-11.

Andersen, Lotte B. 2009. "What Determines the Behaviour and Performance of Health Professionals? Public Service Motivation, Professional Norms and/or Economic Incentives." International Review of Administrative Sciences 75 (1): 79-97.

Andersen, Lotte B., and Søren Serritzlew. 2012. "Does Public Service Motivation Affect the Behavior of Professionals?" International Journal of Public Administration 35 (1): 19-29.

Andersen, Lotte B., and Lene Holm Pedersen. 2012. "Public Service Motivation and Professionalism." International Journal of Public Administration 35 (1): 46-57.

Angle, Harold L., and James L. Perry. 1981. "An Empirical Assessment of Organizational Commitment and Organizational Effectiveness." Administrative Science Quarterly (1981): 1-14.

_.1983. "Organizational Commitment: Individual and Organizational Influences." Work and Occupations 10 (2): 123-46.

Bekke, Hans A. G. M., James L. Perry, and Theo A. J. Toonen, eds. 1996. Civil Service Systems in Comparative Perspective. Bloomington, IN: Indiana University Press.

Berman, Evan. 2017. "City Manager in Three Countries: An Interview with Michael Willis." Public Administration Review 77: 447-452.

Bowman, James S. 1982-83. "A Professional Perspective for PA.” The Bureaucrat, 11 (Winter): 49-52.

Bozeman, Barry. 2007. Public Values and Public Interest: Counterbalancing Economic Individualism. Washington, D.C.: Georgetown University Press.

Brint, Stephen. 1994. In An Age of Experts: The Changing Role of Professionals in Politics and Public Life. Princeton, NJ: Princeton University Press.

Brown, Trevor L., Matthew Potoski, and David M. Van Slyke. 20o6. "Managing Public Service Contracts: Aligning Values, Institutions, and Markets.” Public Administration Review 66 (3): 323-31.

Bryson, John M., Barbara C. Crosby, and Laura Bloomberg. 2014. "Public Value Governance: Moving Beyond Traditional Public Administration and the New Public Management." Public Administration Review 74: 445-456.

Buick, Fiona, Deborah Blackman, Janine O'Flynn, Michael O’Donnell, and Damian West. 2016. "Effective Practitioner-Scholar Relationships: Lessons from a Coproduction Partnership." Public Administration Review 76 $35-47$.

Crewson, Philip E. 1997. "Public-service Motivation: Building Empirical Evidence of Incidence and Effect." Journal of Public Administration Research and Theory 7 (4): 499-518.

Dahl, Robert. 1947. "The Science of Public Administration: Three Problems.” Public Administration Review 7(Winter): 1-11.

Davis, Gerald F. 2015. "Editorial Essay: What is Organizational Research For?" Administrative Science Quarterly 6o: 179-188.

Denhardt, Janet V., and Robert B. Denhardt. 2011. The New Public Service: Serving, Not Steering, 3 rd ed. Armonk, NY: M. E. Sharpe.

_. 2015. "The New Public Service Revisited." Public Administration Review 75: 664-672.

Evans, Tony. 2010. "Professionals, Managers and Discretion: Critiquing Street-Level Bureaucracy." The British Journal of Social Work 41 (2): 368-86.

Feldman, Daniel L. 2015. "The Legitimacy of U.S. Government Agency Power." Public Administration Review 75: 75-84.

Gargan, John J. 2006. "The Public Administration Community and the Search for Professionalism." In Handbook of Public Administration, ed. Jack Rabin, W. Bardey Hildreth, and Gerald J. Miller, 1089-1162. Boca Raton, FL: CRC/Taylor \& Francis.

Gaus, John M. 1936. "The Responsibility of Public Administration.” In The Frontiers of Public Administration, ed. John M. Gaus, Leonard D. White, and Marshall E. Dimock, 26-42. Chicago: University of Chicago Press.

_ - 1947. "The Ecology of Government." Reflections on Public Administration. https://archive.org/stream/reflectionsonpuboogaus\#page/n13/mode/2up.

- 1950. "Trends in the Theory of Public Administration." Public Administration Review 10 (3): 161-68.

Green, Richard T., Lawrence F. Keller, and Gary L. Wamsley. 1993. "Reconstituting a Profession for American Public Administration." Public Administration Review 53 (6): 516-24.

Grimmelikhuijsen, Stephan, Sebasian Jilke, Asmus Olsen, and Lars Tummers. 2017 "Behavioral Public Administration: Combining Insights from Public Administration and Psychology." Public Administration Review 77: 45-56.

Ingraham, Patricia W. 1995. The Foundation of Merit: Public Service in American Democracy. Baltimore, MD: Johns Hopkins University Press.

Jørgensen, Torben Beck, and Barry Bozeman. 2007. "Public Values: An Inventory.” Administration \& Society 39 (3): 354-381.

Jos, Philip H., and Mark E. Tompkins. 1995. "Administrative Practice and the Waning Promise of Professionalism for Public Administration." The American Review of Public Administration 25 (3): 207-229. 
Kim, Sangmook, Wouter Vandenabeele, Bradley E. Wright, Lotte Bøgh Andersen, Francesco Paolo Cerase, Robert K. Christensen, Celine Desmarais, Maria Koumenta, Peter Leisink, Bangcheng Liu, Jolanta Palidauskaite, Lena Holm Pedersen, James L. Perry, Adrian Ritz, Jeannette Taylor, and Paola De Vivo. 2013. "Investigating the Structure and Meaning of Public Service Motivation Across Populations: Developing an International Instrument and Addressing Issues of Measurement Invariance." Journal of Public Administration Research and Theory 23 (1): 79-102.

Kiser, Larry L., and Elinor Ostrom. 1982. "The Three Worlds of Action: A Metatheoretical Synthesis of Institutional Approaches.” In Strategies of Political Inquiry, ed. Elinor Ostrom, 179-222. Beverly Hills, CA: Sage.

Leavitt, Harold J. 1989. "Suppose We Took Groups Seriously." In Readings in Managerial Psychology, 4th ed, eds. Harold J. Leavitt, Louis R. Pondy, and David M. Boje, 410-20. Chicago, IL: University of Chicago Press.

Lindblom, Charles E., and David K. Cohen. 1979. Usable Knowledge: Social Science and Social Problem Solving. New Haven, CT: Yale University Press.

Lipset, Seymour Martin. 1981. Political Man, expanded edition. Baltimore, MD: Johns Hopkins.

Lipsky, Michael. 1980. Street-Level Bureaucracy: Dilemmas of the Individual in Public Services. New York: Russell Sage Foundation.

. 2010. Street-Level Bureaucracy, zoth Ann. Ed.: Dilemmas of the Individual in Public Services. New York: Russell Sage Foundation.

Lynn, Laurence E., Jr. 2009. "Restoring the Rule of Law to Public Administration: What Frank Goodnow Got Right and Leonard White Didn't." Public Administration Review 69: 803-813.

Lynn, Laurence E., Jr., Carolyn J. Heinrich, and Carolyn J. Hill. 2001. Improving Governance: A New Logic for Empirical Research. Washington, DC: Georgetown University Press.

McCabe, Barbara C., Branco Ponomariov, and Fabyan Estrada. 2017. "Professional Cities: Accredited Agencies, Government Structure, and Rational Choice." Public Administration Review. doi:10.1111/puar.12806

Maynard-Moody, Steven, and Michael Musheno. 2003. Cops, Teachers, Counselors: Stories from the Front Lines of Public Service. Ann Arbor: University of Michigan Press.

Meier, Kenneth J. 2015. "Proverbs and the Evolution of Public Administration." Public Administration Review 75: 15-24.

Meynhardt, Timo. 2009. "Public Value Inside: What Is Public Value Creation?" International Journal of Public Administration 32 (3-4): 192-219.

_. 2015. "Public Value-Turning a Conceptual Framework into a Scorecard." In Public Value and Public Administration, ed. John M. Bryson, Barbara C. Crosby, and Laura Bloomberg, 147-169. Washington, DC: Georgetown University Press.

Milward, Brint, Laura Jensen, Alasdair Roberts, Mauricio I. Dussauge-Laguna, Veronica Junjan, René Torenvlied, Arjen Boin, H. K. Colebatch, Donald Kettl, and Robert Durant. 2016. "Is Public Management Neglecting the State?" Governance 29: 311-34.

Monypenny, Phillip. 1953. "A Code of Ethics as a Means of Controlling Administrative Conduct." Public Administration Review 13 (3): 184-7.

Moore, Mark H. 2014. "Public Value Accounting: Establishing the Philosophical Basis." Public Administration Review 74: 465-477.

Mosher, Frederick. 1968. Democracy and the Public Service. New York: Oxford University Press.

Mowday, Richard T., Lyman W. Porter, and Richard M. Steers. 1982. EmployeeOrganization Linkages: The Psychology of Commitment, Absenteeism, and Turnover New York: Academic Press.

Moynihan, Donald P., Sergio Fernandez, Soonhee Kim, Kelly M. LeRoux, Suzanne J. Piotrowski, Bradley E. Wright, and Kaifeng Yang. 2011. "Performance Regimes Amidst Governance Complexity." Supplement 1, Journal of Public Admin istration Research and Theory 21: i141-55.

Nabatchi, Tina. 2012. "Putting the "Public" Back in Public Values Research Designing Participation to Identify and Respond to Values." Public Administration Review 72 (5): 699-708.

Newman, Joshua, Adrian Cherney, and Brian W. Head. 2016. "Do Policy Makers Use Academic Research? Reexamining the "Two Communities" Theory of Research Utilization." Public Administration Review 76: 24-32.

$\mathrm{Ni}$, Chaoqun, Cassidy Sugimoto, and Alice Robbin. 2017. "Examining the Evolution of the Field of Public Administration through a Bibliometric Analysis of Public Administration Review." Public Administration Review 77: 496-509.

O’Toole, Laurence J. 1997. “Treating Networks Seriously: Practical and ResearchBased Agendas in Public Administration." Public Administration Review 57 (1) 45-52.

Perry, James L., ed. 1989. Handbook of Public Administration. San Francisco: Jossey-Bass.
- 1996a. Handbook of Public Administration, Second Edition. San Francisco: Jossey-Bass.

_. 1996b. "Measuring Public Service Motivation." Journal of Public Administration Research and Theory 6 (1): 5-22.

_ 1997. “Antecedents of Public Service Motivation." Journal of Public Administration Research and Theory 7 (2): 181-197.

- 2012a. "How Can We Improve Our Science to Generate More Usable Knowledge for Public Professionals?” Public Administration Review 72: 479-482.

_. 2012b. "Continuity and Change." Public Administration Review 72: 3-8.

—. 2013. "Reflections about Relevance." Public Administration Review 73: 386-387.

_. 2016. "Building Global Public Administration Knowledge." Public Administration Review 76: 533-534.

. 2002. "Review of Improving Governance: A New Logic for Empirical Research by Lynn, L.E., Heinrich, C.J., \& Hill, C.J.” Administrative Science Quarterly 47 (4): $743-745$

- 2007. "Democracy and the New Public Service." The American Review of Public Administration 37 (1): 3-16.

_. 2017. "Where Have You Gone, Harold Seidman?" Public Administration Review 77: 481-482.

Perry, James L., and Lois R. Wise. 1990. “The Motivational Bases of Public Service.” Public Administration Review 50 (3): 367-373.

Perry, James L., and Robert C. Christensen, eds. 2015. Handbook of Public Administration, Third Edition. San Francisco: Jossey-Bass.

Perry, James L., and Wouter Vandenabeele. 2015. "Public Service Motivation Research: Achievements, Challenges, and Future Directions." Public Administration Review 75 (5): 692-699.

Public Administration Review. 2012. "Professionalism in Public Administration and Public Service." Public Administration Review 72 (4): 631-632.

Radin, Beryl. 2013. "Reclaiming Our Past: Linking Theory and Practice." PS: Political Science \& Politics 46 (1): 1-7

Rohr, John A. 1986. To Run a Constitution: The Legitimacy of the Administrative State. Lawrence: University Press of Kansas.

Rosenbloom, David H. 2007. "Reinventing Administrative Prescriptions: The Case for Democratic-Constitutional Impact Statements and Scorecards." Public Administration Review 67 (1): 28-39.

Schott, Richard L. 1976. "Public Administration As a Profession: Problems and Prospects." Public Administration Review 36 (3): 253

Simon, Herbert A. 1946. “The Proverbs of Administration.” Public Administration Review 6 (1): 53-67.

Stever, James A. 1987. The End of Public Administration: Problems of the Profession in the Post-Progressive Era. Dobbs-Ferry, NY: Transitional.

Streib, Greg. No date. "Revisting the Case for Professsionalizing Public Administration." Working Paper. Atlanta, GA: Andrew Young School of Policy Studies, Georgia State University.

Sullivan, William M. 2005. Work and Integrity: The Crisis and Promise of Professionalism in America, Second Edition. San Francisco: Jossey-Bass.

Svara, James H. 2014. "Who Are the Keepers of the Code? Articulating and Upholding Ethical Standards in the Field of Public Administration." Public Administration Review 74 (5): 561-569.

Teodoro, Manuel P., and Adam G. Hughes. 2012. "Socializer or Signal?, How Agency Accreditation Affects Organizational Culture." Public Administration Review 72: 583-591.

Volcker, Paul A. 2014. "Vision Without Execution Is Hallucination." Public Adminis tration Review 74: 439-441.

Waldo, Dwight. 1968. "Scope of the Theory of Public Administration." In Theory and Practice of Public Administration: Scope, Objectives, and Methods, ed. James C. Charlesworth, 1-26. Philadelphia: American Academy of Politica and Social Science.

. 1988. The Enterprise of Public Administration: A Summary View. Novato, CA: Chandler and Sharp.

Watts, Duncan J. 2017. "Should Social Science be More Solution-oriented?" Nature Human Behaviour 1: 0015

Willbern, York. 1954. "Professionalization in the Public Service: Too Little or Too Much?" Public Administration Review 14 (Winter): 13-21.

Wilson, Woodrow. 1887. “The Study of Administration." Political Science Quarterly 2 (2): 197-222.

Wright, Bradley. 2015. "The Science of Public Administration: Problems, Presumptions, Progress, and Possibilities." Public Administration Review 75 (6): 795-805. 